Short Communication

\title{
BRUCELLOSIS IN TRADE CATTLE IN LAGOS STATE: AN INVESTIGATION OF TWO ABATTOIRS
}

\author{
CADMUS ${ }^{\prime *}$, S.I.B., OSIKOYA ${ }^{2}$, I.E., ADESOKAN ${ }^{1}$, H.K. \\ 'Department of Veterinary Public Health and Preventive Medicine, \\ University of Ibadan, Ibadan, Nigeria. \\ 'Department of Animal Production and Fisheries, School of Agriculture, \\ Lagos State Polytechnic, Ikorodu, Lagos, Nigeria \\ *Correspondence: sibcadmus@yahoo.com.Tel: 234-0802-375-1093

\section{INTRODUCTION}

Brucellosis affects domestic and wild animals as well as humans (Charters, 1980). Humans are usually affected due to zoonotic transmission from aninals (mostly ruminants). Bovine brucellosis is usually caused by Brucella abortus, less frequently by $B$. melitensis, and rarely by $B$. suis (FAO, 2003). It is usually manifested by abortion, with excretion of the organisms in uterine discharges and in milk. Diagnosis depends on the isolation of Brucella sp. from aborted material, udder secretion or from tissues removed at post-mortem examination. On the other hand, Brucella antigens can be demonstrated through specific cell mediated or serological reactions (FAO, 2003). The disease is endemic in Nigeria's livestock (Adamu and Ajogi, 1999; Ishola and Ogundipe, 2001) and serological prevalence rates of between $0.20 \%$ and $79.70 \%$ have been reported in various parts of the country (Ocholi et al., 1993). Evidence of the presence of the disease in hum ans in Nigeria has also been published (Alausa and Osoba, 1977; Falade, 2 . 22; Cadmus et al; 2006), therefore pointing at its public health implications. Lagos State is the second most populous state in Nigeria (NPC, 2006) and the economic nerve centre of the nation. Beef constitutes a $v$ ajor source of protein for the people in the state and equally a ready source of transmission of zoonotic diseases. Since the last documented report of bovine brucellosis in Lagos State was about three decades ago (Esuruoso and Ayanwale, 1980), we therefore sought to determine the current status of the disease among trade cattle in the state.

\section{MATERIALS AND METHODS}

\section{Duration and location of the study}

The survey was carried out over a period of three months (July to September, 2007) at the Ikorodu and Oko-Oba abattoirs, which are among the thirteen legally operated abattoirs/slaughter slabs in the state. The two abattoirs were chosen because each of them is located closely to one of the two control posts operated by the government; hence, ability to have a fair picture of animals brought to the state through different routes. Since more cattle are slaughtered in Oko-Oba abattoir (being the largest in the state), we therefore screened more animals here than those in lkorodu. Majority of the cattle slaughtered in these abattoirs were from the northern parts of Nigeria and others from the neighbouring African countries of Benin Republic, Burkina Faso, Cameroon, Chad, Mali and Niger. 


\section{Sample collection}

In all, a total of 479 cattle were screened; 126 from lkorodu and 353 from Oko-Oba. The breed, sex and age of the animals were identified and documented. Labelled sterile vacuutainer tubes were used to collect blood from animals at the time of slaughter and kept in containers prior to transportation to the laboratory. Blood samples were centrifuged at $3000 \mathrm{~g}$ for 10 minutes and the sera decanted and stored in the freezer at -4 " $\mathrm{C}$ until required for testing.

\section{Rose Bengal test (RBT)}

The RBT was performed according to the procedure described by Alton et al. (1988). The Brucella abortus RBT antigen [supplied by Veterinary Laboratory Agency (VLA), Surrey, United Kingdom] was used for this test.

\section{Statistical Analysis}

The data were analyzed using the Chi square method.

\section{RESULTS AND DISCUSSION}

A prevalence of $8.6 \pm 1.78 \%(C .1 .=6.1-11.1)$ was obtained from the total population of cattle screened and one hundred and twenty six of them (85 males and 41 females) were from Ikorodu abattoir. Out of these, $11(8.7 \pm 7.53 \%$ C.1. $=6.1$ $11.1)$ were sero-positive for brucellosis including $5(5.9 \%)$ males and $6(14.6 \%)$ females (TABLE I). On the other hand, 353 cattle (210 males and 143 females) of the total population were from OkoOba abattoir, $30(8.5 \pm 1.88 \%$ C.I. $=6.1-11.1 \%)$ of which were sero-positive for brucellosis (i.e. 16 $(7.6 \%)$ males and $14(9.8 \%)$ females) (TABLE I). The lkorodu abattoir had a higher proportion of infection ( $8.7 \pm 7.53 \%$ ) when compared with $8.5 \pm$ $1.88 \%$ recorded at Oko-Oba; however, this difference was not significant $\left({ }^{2}=0.01 ; \mathrm{P}>0.05\right)$.
Out of the 479 cattle screened from the two abattoirs, all of which were adults; 295 were males and 184 were females; with 41 (8.6 \pm $1.78 \%$ ) cattle sero-positive overall (i.e. 21 (7.1 $\pm 3.91 \%)$ and $20(10.9 \pm 7.75 \%)$ males and females, respectively; Table 1), but the difference among the gender was not significant $\left({ }^{2}=1.59 ; \mathrm{P}>0.05\right)$.

The difference in the prevalence obtained at the two abattoirs was not statistically significant $\left({ }^{2}=0.01 ; \mathrm{P}>0.05\right)$. The overall prevalence of $8.6 \%$ obtained in this survey is similar to previous studies in the southwestern region of the country; 5.82\% (Cadmus et al.; 2006); $6.28 \%$ (lshola and Ogundipe, 2001 ); and $6.79 \%$ (Ogundipe et al, 1994). It shows therefore, that the prevalence of the disease is similar; implying endemicity of the disease in trade cattle. One of the reasons for this could be due to the manner in which these animals are congregated together at different cattle markets and during transportation over a long period of time prior to slaughter in the state. This scenario allows for transmission of the disease between healthy and infected animals since transmission is possible through direct contact with skin abrasions and mucus membranes such as conjunctiva. 
TABLE I: Prevalence rates among the different breeds of cattle screened at lkorodu and Oko-Oba abattoir, lagos State

\begin{tabular}{|c|c|c|c|c|c|c|c|c|c|c|}
\hline Location & Breed & $\begin{array}{c}\text { Total } \\
\text { samiple } \\
\text { collectedl }\end{array}$ & Male & $\begin{array}{c}\text { Male } \\
+\operatorname{ve}(\%)\end{array}$ & Female & $\begin{array}{l}\text { Female } \\
\text { tve }(\%)\end{array}$ & $\begin{array}{c}\text { No +ve } \\
\text { in total } \\
\text { sample } \\
\text { (1\%) }\end{array}$ & $\begin{array}{l}2 \text { (over: } \\
\text { prevalence) }\end{array}$ & 2 (se) & 2 (breed) \\
\hline & $\begin{array}{l}\text { White } \\
\text { Fulani }\end{array}$ & 17 & II & $2(18.2)$ & 6 & $1(16.7)$ & $.3(17.6)$ & \multirow{14}{*}{$\begin{array}{l}0.01 \\
(P=0.05)\end{array}$} & \multirow{14}{*}{$\begin{array}{l}1.59 \\
(P>0.05)\end{array}$} & \multirow{14}{*}{$\begin{array}{l}0.55 \\
(P>0.05)\end{array}$} \\
\hline & $\begin{array}{l}\text { Sokoto } \\
\text { Gudali }\end{array}$ & 53 & 39 & $1(2.6)$ & 14 & $2(14 . .3)$ & $3(5.7)$ & & & \\
\hline IKORODU & $\begin{array}{l}\text { Red } \\
\text { Rororo }\end{array}$ & 30 & 14 & $0(0.0)$ & 16 & $1(6.3)$ & $1(3.3)$ & & & \\
\hline ABATTOIR & Mixed & 8 & 8 & $1(12.5)$ & 0 & $0(0.0)$ & $1(12.5)$ & & & \\
\hline & Kuri & 17 & 13 & $1(7.7)$ & 4 & $2(50.0)$ & $3(17.6)$ & & & \\
\hline & Keteku & 1 & 0 & $0(0.0)$ & 1 & $0(0.0)$ & $0(0.0)$ & & & \\
\hline . & $\begin{array}{l}\text { Total } \\
\text { White } \\
\text { Fulani }\end{array}$ & $\begin{array}{l}126 \\
64\end{array}$ & $\begin{array}{l}85 \\
42\end{array}$ & $\begin{array}{l}5(5.9) \\
2(4.8)\end{array}$ & $\begin{array}{l}41 \\
22\end{array}$ & $\begin{array}{l}6(14.6) \\
4(18.2)\end{array}$ & $\begin{array}{l}11(8.7) \\
6(9.4)\end{array}$ & & & \\
\hline & $\begin{array}{l}\text { Sokoto } \\
\text { Gudali }\end{array}$ & 123 & 90 & $6(6.7)$ & 33 & $2(6.1)$ & $8(6.5)$ & & & \\
\hline OKO OBA & $\begin{array}{l}\text { Red } \\
\text { Bororo }\end{array}$ & 93 & 37 & $5(1.3 .5)$ & 50 & $5(8.9)$ & $10(10.8)$ & & & \\
\hline \multirow[t]{4}{*}{ ABATTOIR } & Mixed & 19 & 15 & $2(1.3 .3)$ & 4 & $0(0.0)$ & $2(10.5)$ & & & \\
\hline & Kuri & 44 & 18 & $0(0.0)$ & 26 & $3(11.5)$ & $3(6.8)$ & & & \\
\hline & Keteku & 10 & 8 & $1(12.5)$ & 2 & $0(0.0)$ & $1(10.0)$ & & & \\
\hline & Total & 353 & 210 & $16(7.6)$ & 143 & $14(9.8)$ & $30(8.5)$ & & & \\
\hline COMBINED & Total & 479 & 295 & $21(7.1)$ & 184 & $20(10.9)$ & $41(8.6)$ & & & \\
\hline
\end{tabular}

It was observed that a higher prevalence $(10.90 \%)$, though not statistically significant was obtained in female cattle when compared with $7.1 \%$ among the males $(=1.59 ; \mathrm{P}>0.05)$. This is similar to the findings of Ishola and Ogundipe (200l) in a study conducted in Ibadan, where $4.18 \%$ and $4.50 \%$ were obtained for the female and male cattle respectively, with no significant difference $\left(\left(^{2}=1.135 ; \mathrm{P}>0.05\right)\right.$. This therefore indicated that the disease is not sex-dependent.

From our results, the most affected breeds were the White Fulani and the mixed breeds (11.1\% each); however, there was no significant difference in the infection rates amongst the breeds screened $(=0.55 ; \mathrm{P}>0.05)$. A similar finding was obtained by Cadmus et al., (2006), where the most affected breed was the White Fulani (though this breed also constituted the larger population in the study). However, other studies (Ishola and Ogundipe, 2001) have indicated higher prevalence in other breeds than the White Fulani therefore justifying the non dependence of the disease on breed.
Judging from the prevalence of brucellosis in these two abattoirs, it can be inferred that this disease poses a real threat to the consuming pubiic, and particularly to livestock traders and those directly involved in the processing of meat in the abattoirs and at home. Tris therefore buttresses earlier findings of Esuruoso and Ayanwale (1980) on the food safety risks and occupational hazards of brucellosis. Moreover, Alausa (1979) asserted that brucellosis is associated with sickness, misery and economic loss than most zoonotic diseases in both humans and animals; hence, resulting in illness and loss of manpower with additional serious reduction of much needed animal proteins in human nutrition.

\section{CONCLUSION}

In conclusion, given the prevalence of brucellosis in trade cattle in these abattoirs, there is the need to put in place serological screening measures for the infection before cattle are transported to the different abattoirs in the state. Abattoir workers should also wear protective 
clothing and observe a high level of hygiene in the course of their work.

\section{ACKNOWLEDGEMENT}

We thank Judy Stack of the Department of Statutory \& Exotic Bacteria of the Veterinary Laboratories Agency (VLA), United Kingdom for supplying the antigen used for this work.

\section{REFERENCES}

ADAMU, N.B. and AJOGl, I. (1999): Serological investigation of camels ( $C$ amelus dromadarius) slaughtered at Kano Municipal Abattoir for evidence of brucellosis. Trop. Vet., 18:45-48.

ALAUSA, O. K. and OSOBA, A. O. (1977): Subclinical human Brucella infection in Ibadan, Nigeria. Ghana Med. J., 16:251254.

ALTON G.G, JONES L.M., ANGUS R.D and VERGER J.M. (1988): Techniques for the brucellosis laboratory. Institut National de la Recherche Agronomique, Paris; 187.

CADMUS, S.I.B., IJAGBONE, I.F., OPUTA, H.E., ADESOKAN, H.K and STACK,

J.A. (2006): Serological survey of brucellosis in livestock animals and workers in Ibadan, southwestern, Nigeria. Afr. J. Biomed. Res., 9:163-168.

CHARTERS, A.D. (1980): Brucellosis. Australian Family Physician, 9:707-712.

ESURUOSO, G.O. and AYANWALE, F.O. (1980): Brucellosis in Lagos State of
Nigeria. Bull. Anim. Hlth. Prod. Afr., 28:11-15.

FALADE, S. (2002): A case of possible brucellosis relapse in a veterinarian. Trop. Vet. 20:226-230.

FAO (2003): Guidelines for coordinated human and animal brucellosis surveillance. FAO

Animal Production and Health Paper 156: $1-46$.

ISHOLA, O.O. and OGUNDIPE, G.A.T. (2001): Sero-prevalence of brucellosis in trade cattle slaughtered in lbadan, Nigeria. Trop. Vet., 19:1720.

NATIONAL POPULATION COMMISSION. (2006). Population census. National Population Census, Nigeria.

OCHOLI, R.A., KALEJAIYE, I.O. and OKEWOLE, P.A. (1993): Brucellosis in Nigeria: a review. Trop. Vet., 11:15-26.

OGUNDIPE, G.A.T., OYEYEMI, M.O. and IJAGBONE, I.F. (1994): Seroprevalence of Brucella abortus agglutinins in slaughtered cattle in ,lbadan. Trop. Vet., 12:158-161. 